\title{
Evaluation of the performance of tolerant crosses of oil palm selected in prenursery and replanted on wilt disease areas
}

\author{
Diabate Sekou ${ }^{1}$, Traore Aboulaye $^{2}$, Kone Boake ${ }^{3}$ \\ CNRA, Laboratoire Central de Biotechnologies 01 BP 1740 Abidjan 01, Côte d'Ivoire \\ UFR- SN, université d'Abobo - Adjamé, 01 BP 801 Abidjan 01, Côte d'Ivoire \\ CNRA, Station de recherche de La Mé 13 B.P 989 Abidjan 13, Côte d'Ivoire \\ Corresponding author (E-mail: sekou diabate2002@yahoo.fr)
}

\begin{abstract}
An early test of inoculation of Fusarium oxysporum f. sp. elaeidis is performed on plants aged 3 months from crosses of oil palm (Prenursery stage). At the end of the test (5 months after inoculation) each crossing is credited with a wilt disease tolerance index. Thus, crosses with an index below 100 are the most tolerant to wilt. The behavior of these crosses was then confirmed in adult age, in replanting on old areas infected by wilt disease by an epidemiologic control. The observations have shown that the oldest crops have suffered on average 20 to $30 \%$ of wilt disease, which decreased steadily over successive programs of selection of crosses in prenursery, despite the replanting conditions which confronted the plant material to a high risk of wilt disease. The epidemiological controls of wilt disease of oil palm in replanting has shown that it could be a disease of young age in replanting if the first generation of oil palm expressed a high level of wilt disease. The performance of tolerant crosses selected in prenursery and members of the same progeny is observed in five blocks of first generation plantations which were cut down because they were partly decimated by wilt disease. The observations have shown that wilt disease of oil palm has been significantly reduced in replanted fields thanks to the combination effect of genetic selection in prenursery and cultural practices regardless of the incidence of wilt disease during the first generation of oil palm plantations, thus confirming tolerance of crosses tested in young age.
\end{abstract}

Keywords: Wilt disease, replanting, generation, tolerant, oil palm.

\section{INTRODUCTION}

The vascular wilt of oil palm, which pathogenic cryptogam is Fusarium oxysporum f. sp. elaeidis, is by far the most serious disease of oil palm cultivation in Africa (Durand et al., 2002). In Côte d'Ivoire, it has been observed in the savannah zone of Dabou as well as in the South East forest zone (Renard et al., 1972). Wilt disease can affect more than $50 \%$ of trees planted, according to the type of soil, the previous crop and the plant material (Franqueville, 1984; Franqueville et Renard, 1990).

Specific data were collected in Côte d'Ivoire on the Robert Michaux plantation (4000 ha) near Dabou, and indicated that wilt disease is a disease of old age in extension (first cycle of cultivation) where it appeared between 8 and 10 years; on the contrary, data showed that it was a disease of young age in replanting where it appeared in the first year of cultivation if the material planted was sensitive (Franqueville et Renard, 1990). In both cases, the disease stabilizes four years after the appearance of symptoms and recoveries are sometimes observed when tolerant materiel is planted. Chemical control being ineffective on the areas concerned, the only efficient method of control without which no decline in the disease could be achieved remained the selection of resistant oil palms from an inoculation test in prenursery stage (Renard et al. 1980; Franqueville and Diabaté, 1995).

This study aims at evaluating the behaviour of crosses from the same progeny. These crosses were selected for their tolerance to wilt disease in prenursery and were planted in blocks that have been cut down as they were strongly affected by wilt disease in first generation of oil palm cultivation.

\section{MATERIALS AND METHODS}

Biological material: The material used was of oil palm crosses from the progeny tolerant to wilt disease, DA 115 D X LM 2T. These crosses have been subject to wilt disease selection test in 
prenursery after which they were considered tolerant( with wilt index $<100$ ).

Method of Planting: The total area of the Robert Michaux plantation in Dabou was divided into basic units of 100 hectares called "blocks". Each block was subdivided into 16 plots of land of 6.25 ha each. The plots were numbered as follows:

- 1 to 4 ;

- 11 to 14

- 21 to 24

- 31 to 34 .

The blocks were designated by capital letters followed by a number indicating the block number (example: E3, F5, G5, etc.). All the crosses considered tolerant after the inoculation tests of the pathogen of wilt disease at prenursery, were planted in lines marked and controlled periodically on the plantation blocks about wilt disease.

For this study blocks D3, E4, F4, F5 and G5 were chosen because they hosted crosses which have shown a high level of wilt disease in first generation (Table 1) and were replanted later by crosses - tested in prenursery against wilt disease - from the tolerant descent DA 115D x LM 2T. These blocks were replanted in 1995 and make up the second generation of palm trees planted on these blocks. The report on wilt disease was conducted in 2005, five years after the stabilization of the disease.

Table 1: Percentage of wilt disease expressed on the blocks of first generation oil palm.

Blocks (year of planting) \% Wilt disease

\begin{tabular}{|llc|}
\hline D4 & $(1961-1962)$ & 20 \\
\hline E4 & $(1956-1958)$ & 24 \\
\hline F4 & $(1957-1958)$ & 21 \\
\hline F5 & $(1959-1958)$ & 14 \\
\hline G5 & $(1965)$ & 29 \\
\hline
\end{tabular}

Methods of observation of wilt disease: A regular monitoring of the field behaviour of these crosses was performed by successive controls. The frequency of the controls was higher in young crops than in adult plantations regarding the earliness of wilt disease in replanting: thus 4 annual controls were made for plots from 0 to 5 years, 3 controls for those from 6 to 8 years and 2 controls for plots over 8 years. The data were gathered by plot and by year of cultivation and enabled to calculate the percentage of wilt disease expression.

Statistical analysis: The statistical analysis of all the data were performed using the SPSS 13.0.1 software. This software enabled to perform the variance analysis at the threshold of $5 \%$ and when a significant difference was detected, homogeneous groups were formed from the DUNCAN test.

\section{RESULTS}

The results obtained in block D3 (Figure 1) showed a strong presence of wilt disease with a high peak of $25.4 \%$ in plot 22 in first generation. In second generation the disease expression was significantly reduced to less than $2.5 \%$ in all the plots of the block.

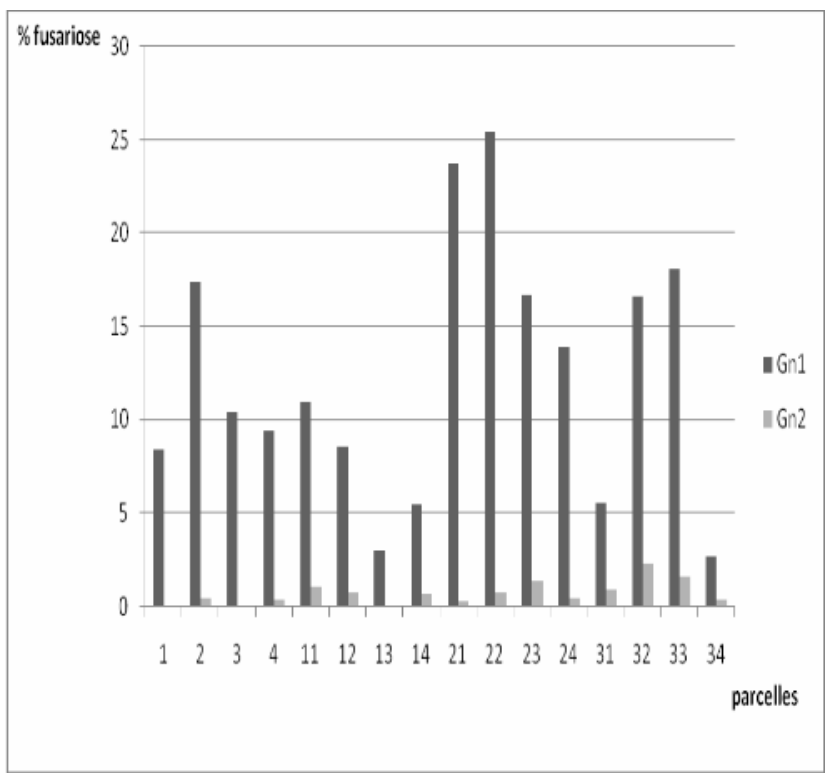

Fig 1: Influence of vascular wilt disease in a first planting and in a replanting: the case of block D3

Gn1 = First generation

$\mathrm{Gn} 2=$ Second generation

As for block E4 (Figure 2) the results showed that all the plots of the block were strongly affected by wilt disease in first generation of oil palm, particularly plot 4 , which showed more than $50 \%$ of wilt disease. In second generation however the expression was significantly reduced to less than $5 \%$ in all the plots. 


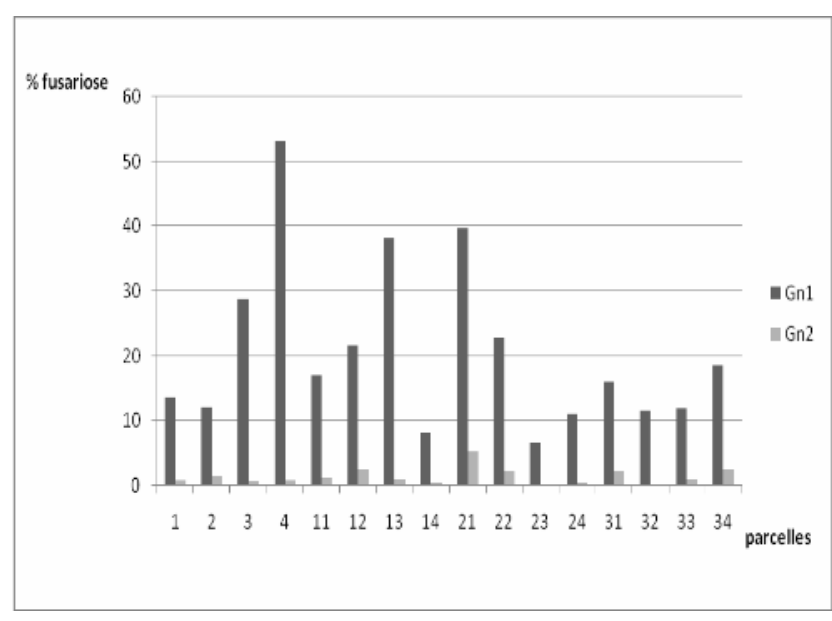

Fig 2: Influence of wilt disease in a first planting and in replanting: the case of block E4

Gn1 = First generation

$\mathrm{Gn} 2=$ Second generation

Regarding block F4 (Figure 3), the results indicated that all the plots were affected by wilt disease in first generation, particularly plots 4, 14, 24 and 34 which showed more than $30 \%$ of wilt disease. In second generation, the expression of wilt disease has declined on average in all the plots (less than $5 \%$ of wilt disease) except plots 14 and 24 which showed respectively $5.7 \%$ and $10.3 \%$ of wilt disease.

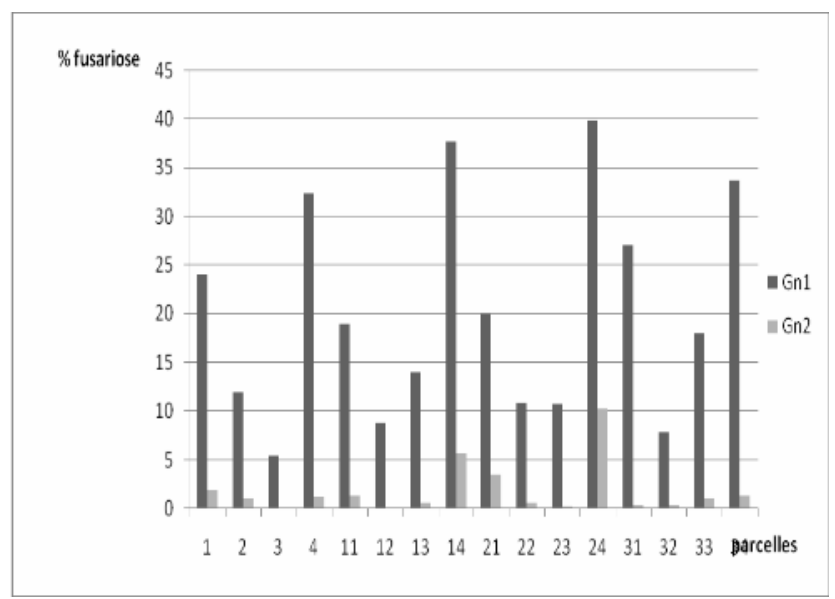

Fig 3: Influence of vascular wilt disease in a first planting in replanting: the case of block F4

Gn1 = First generation

Gn2 = Second generation

Concerning the behaviour of crosses in the block F5 (Figure 4), the results showed that the disease appeared more than $10 \%$ on average in all the plots in first generation. In second generation of oil palm planted however, the disease appeared less (less than $2 \%$ on average).

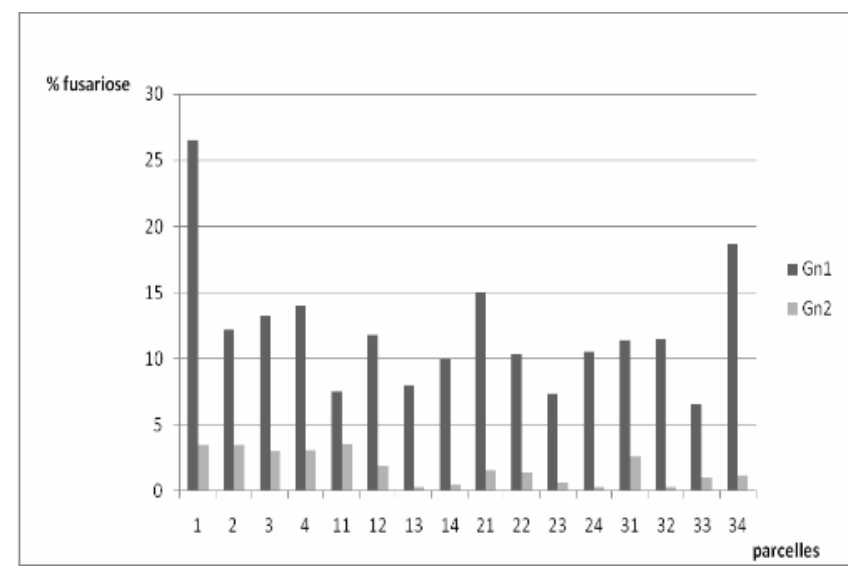

Fig 4: Influence of wilt disease in first planting and in replanting: the case of block F5

$\mathrm{Gn} 1=$ First generation

$\mathrm{Gn} 2=$ Second generation

Figure 5 presented the expression of wilt disease in block G4 on both generations of oil palm. The results of observations indicated that this block was clearly the most affected by wilt disease in relation to the other blocks with more than 30\% on average per plot. In second generation, wilt disease has dropped to less than 3\% except plots 21 and 22 that were affected respectively by 18.6 and $6.8 \%$ of wilt disease.

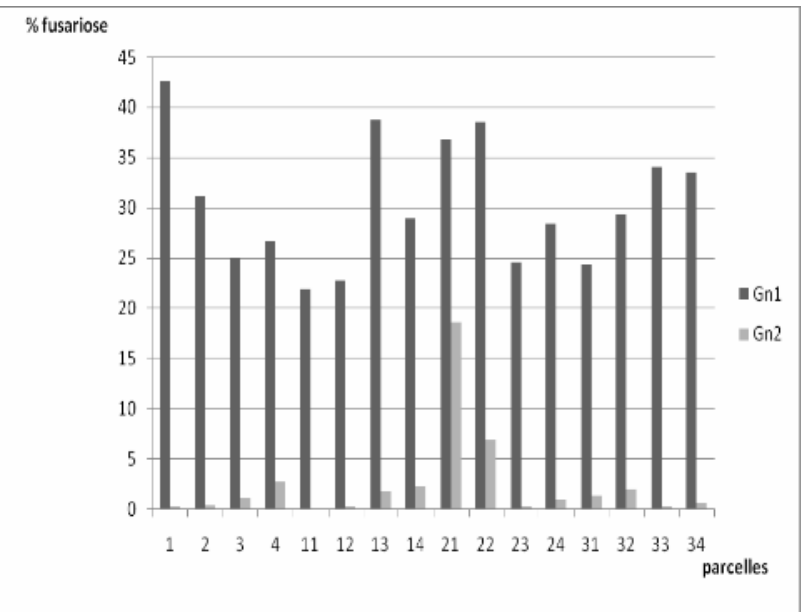

Fig 5: Influence of vascular wilt disease in first planting and in replanting: the case of block $\mathrm{G} 4$

Gn1 = First generation

Gn2 = Second generation 
The type of disease encountered during these observations was chronic wilt disease characterized by a stunting of the oil palm and a narrowing of the stipe into pencil point (Figure 6). The oil palms affected, produce very few and very poor bunches and their growth stopped.
These results are corroborated by variance analysis (Table 2); significance at the threshold of $5 \%$ was noted between both generations of oil palms planted. The first generation showed wilt disease more than the second one. No significant difference was obtained between the plots.

Table 2 : Variance analysis

\begin{tabular}{|c|c|c|c|c|c|c|}
\hline $\begin{array}{l}\text { Source of } \\
\text { variation }\end{array}$ & S.S. & dl & M. S & F.v & F .th & p. value \\
\hline \multirow{3}{*}{$\begin{array}{l}\text { Blocks } \\
\text { Generations } \\
\text { Plots }\end{array}$} & 813.73 & 4 & 203.43 & $3.49 *$ & 2,49 & $<0.05$ \\
\hline & 8429.88 & 1 & 8429.88 & $144.66^{\star \star \star}$ & 3,96 & $<0.001$ \\
\hline & 888.21 & 15 & 59.21 & $1.02 \mathrm{~ns}$ & 1,79 & $>0.05$ \\
\hline \multirow{2}{*}{$\begin{array}{l}\text { Residual } \\
\text { TOTAL }\end{array}$} & 4720.09 & 81 & 58.27 & & & \\
\hline & 16406.24 & 101 & & & & \\
\hline
\end{tabular}

Legend: S.S. $=$ Sum of Square; $\mathrm{dl}=$ freedom liberty; M.S. = Mean square; F.v = Fisher values: $\left(^{*}\right)$

$=\mathrm{p}$ value $<5 \% ;(* \star *)=\mathrm{p}$ value $<0.1 \% ; \mathrm{F}$. th $=$ Fisher theorical values; $\mathrm{ns}=$ not significant.

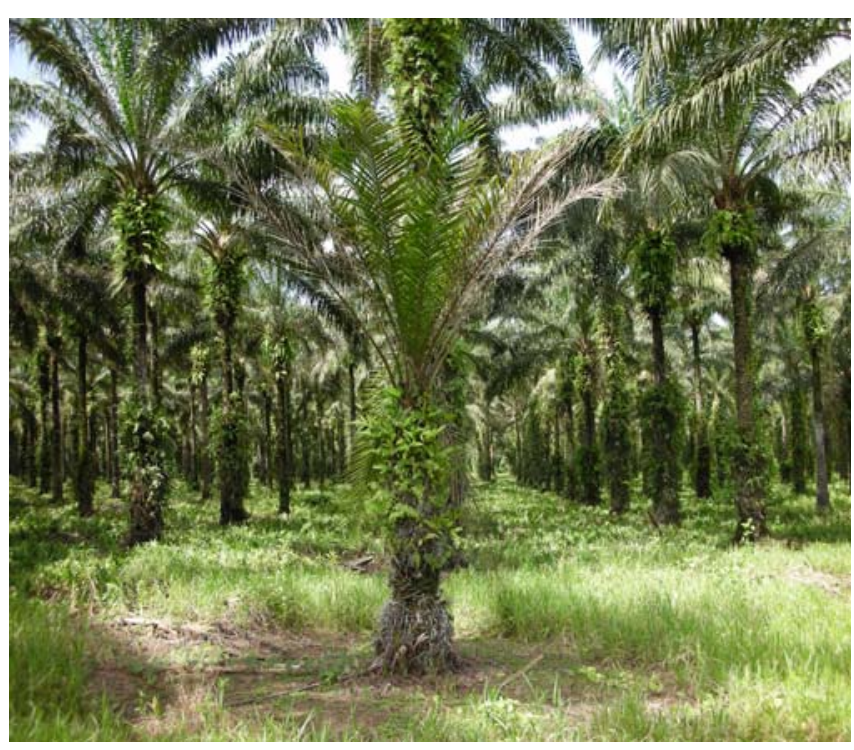

Fig 6: Chronic wilt disease in palm tree in production

\section{DISCUSSION}

Our results showed a higher incidence of wilt disease in first generation of oil palm plantations than in second generation ones at Robert Michaux, a savannah area. This first-generation material planted before the 1970 from several origins has not been subject to any test of tolerance to wilt disease (Meunier et al., 1979).
The impact of wilt disease on the palm trees planted in first generation has demonstrated the need to pay great attention to environmental factors and the sensitivity of plant material (Franqueville, 1984; Franqueville et Renard, 1990; Franqueville et Diabaté, 2004). In terms of environmental factors, the responsiveness of the soil played a major role in the infection of the plant material (Boake et Ouvrier., 1995); the density of inoculum in the soil and their pathogenic activity favoured the expression of wilt disease in first generation of oil palm (Alabouvette et al., 1985). Indeed, in the Robert Michaux plantation, a strong pathogenic activity of Fusarium oxysporum $\mathrm{f}$. sp. elaeidis was revealed by Yao (1993) in soils hosting first generation palm trees as well as in second generation ones. The plant material of the first generation which has not been tested for tolerance to wilt disease was heavily colonized by the pathogen very active in the soils: this is then the reason why many cases of wilt disease have been identified in most of the plots of the blocks studied in first generation.

Our results also showed that in second generation of palm trees planted, despite intense parasite pressure caused by the palm trees of the first generation, the rates of palm trees affected by wilt disease fell significantly (less than 5\%) in all the blocks. This decrease was explained by the combination of research of plant material tolerant to wilt disease from early tests in prenursery and the role of cultural practices recommended for replanting in wilt disease areas (Franqueville, 1984; Franqueville et Renard, 
1988; Franqueville et Diabaté, 1995). Indeed, from 1970 , inoculation tests in prenursery were developed (Renard et al., 1972). Many sources of tolerance have been identified (Durand et al., 2000). The fullscale confirmation of the validity of these early tests was therefore brought by this study at Robert Michaux.

Moreover, certain cultural practices recommended for replanting were able to modulate the impact of the disease (Allou et al., 2001). Indeed, De Franqueville et Diabate (1995) showed that the percentage of wilt disease could be reduced by half if the young palm trees were replanted more than 2 meters away from the old stumps of first generation oil palms.

Thus, selection tests in prenursery and cultural practices have favoured a weak expression of wilt disease in second generation despite the high pressure from Fusarium oxysporum f. sp. elaeidis observed in first generation.

\section{CONCLUSION}

The vascular wilt of oil palm is a young age disease at replanting: it progresses rapidly during the first three years before stabilizing. The privileged means of control and without which the plant can not be grown in wilt disease areas without major risk, remains the selection of tolerant plant material in prenursery. Thanks to these selection tests and cultural practices to be applied during replanting in wilt disease areas, our study has shown that the disease was poorly expressed on the whole of the blocks observed and it often disappeared on some plots of second generation oil palm although the plant material in replanting was facing a high risk of contamination by the pathogen in the soil. The tolerance of the crosses selected in prenursery is thus confirmed in replanting on wilt-affected old areas. These tolerant crosses are actually proposed for replanting in all areas affected by wilt disease in Africa and in the World.

\section{REFERENCES}

Alabouvette C., Couteaudier Y., Louvet J., 1985. Recherche sur la résistance des sols aux maladies XII - Activité respiratoire dans un sol résistant et un sol sensible aux fusarioses vasculaires enrichis en glucose. Agron. 5 : 69-72.

Allou K., Ake S., Ahoussou N., Ballo K., Diabaté S., 2001. Effet de la jachère sur l'expression de la fusariose vasculaire du palmier à huile (Elaeis guineensis jacq) Agron. AFR. 12(1): 21-33.
Boake K. et Ouvrier M., 1995. Dynamique des minéraux sous palmeraie.Agon. Afr 7(1) :1-12

Durand-Gasselin T., Diabaté S., Franqueville $\mathrm{H}$. (de)., Cochard B., Adon B., 2000. Assessing and utilizing sources of resistance to Fusarium wilt oil palm (Elaeis guineensis jacq) genetic resources In: international symposium on oil palm genetic resources and utilizing, 8-10 June 2000. MPOB - Malasya: 105110.

Durand-Gasselin T., Cochard B., Amblard P., Franqueville H. (de)., 2002. Un regard sur quarante ans d'amélioration génétique du palmier à huile (Elaeis guineensis jacq) et son impact sur la filière. Le Sélectionneur Français (53) ISSNO. 374 : 16-21.

Franqueville (de) H., 1984. La fusariose vasculaire du palmier à huile: relation entre la résistance en pépinière et la résistance en champ. Oléagineux. 39 (11) : 513-518.

Franqueville (de) H. et Renard J.L., 1988. La fusariose du palmier à huile en replantation : méthodes d'études et mise en évidence de quelques facteurs de l'environnement sur l'expression de cette maladie. Oléagineux. 43 (4) : 149-155.

Franqueville (de) H. et Renard J.L., 1990. Bilan de l'amélioration du niveau de tolérance du palmier à huile à la fusariose. Evolution de la maladie sur la plantation R. Michaux. Oléagineux. 45 (10) : 399-405.

Franqueville (de) H. et Diabaté S., 1995. La fusariose du palmier à huile en Afrique de l'Ouest. Plantation, Recherche, Développement. Juillet-Août : 5-10.

Franqueville (de) H. et Diabaté S., 2004. Notes on oïl palm vascular wilt. Communication présentée au Malaysian Palm oil Board (MPOB) Mai 2004. Malaisie : 1-8.

Meunier I., Renard J.L., Quillec G., 1979. Hérédité de la résistance à la fusariose chez le palmier à huile. Elaeis guineensis jacq. Oléagineux. 34 (12) : 555-561.

Renard J.L., Gascon J.P., Bachy A., 1972. Recherche sur la fusariose du palmier à huile. Oléagineux. 35 (8-9) : 387-393.

Renard J.L., Noiret J.M., Meunier J., 1980. Sources et gammes de résistance à la fusariose chez le palmier à huile. Elaeis guineensis et Elaeis melanococca. Oléagineux. 39 (8-9) : 387-393.

Renard J.L. et Quillec G., 1984. Les maladies graves du palmier à huile en Afrique et en Amérique du Sud. Oléagineux. 39 (2) : 57-63.

Yao D.C., 1993. Contribution aux recherches sur la réceptivité des sols à la fusariose vasculaire du palmier à huile. Mémoire du Diplôme d'Agronomie Approfondie. ESA de Yamoussoukro (Côte D'Ivoire), $67 \mathrm{p}$. 